\title{
THE EFFECTIVENESS OF DRAMA TO TEACH SPEAKING VIEWED FROM STUDENTS' SELF-ACTUALIZATION
}

\author{
Senny Wiyanti ${ }^{1}$, Abdul Asib ${ }^{2}$, Ngadiso ${ }^{3}$ \\ ${ }^{1}$ IKIP PGRI Pontianak \\ ${ }^{2}$ Sebelas Maret University Surakarta \\ ${ }^{3}$ Sebelas Maret University \\ ${ }^{1}$ sennywiyanti09@gmail.com
}

\begin{abstract}
The main objective of the research is to find out: (1) whether Drama technique is more effective than Guided Conversation Activity Technique to teach Speaking; (2) whether the students who have high self-actualization have better speaking skill than those who have low self-actualization; and (3) whether there is an interaction between teaching techniques and students' self-actualization. The method of this research was quantitative research using experimental design. The research findings are: (1) Drama Technique is significantly different from Guided Conversation Activity (GCA) technique to teach speaking because Fo is higher than Ft. (2) the speaking skill of the students who have high self-actualization is significantly different from that of those who have low selfactualization if viewed from the result of ANOVA because Fo is higher than Ft. (3) there is an interaction between teaching techniques and self-actualization for teaching speaking because Fo is higher than Ft.
\end{abstract}

Keywords: drama, self actualization, guided conversation, speaking.

\begin{abstract}
Abstrak
Tujuan utama dari penelitian ini adalah untuk mengetahui: (1) apakah teknik Drama lebih efektif daripada Teknik Aktivitas Percakapan Berpanduan untuk mengajar Berbicara; (2) apakah siswa yang memiliki aktualisasi diri tinggi memiliki keterampilan berbicara yang lebih baik daripada siswa yang memiliki aktualisasi diri rendah; dan (3) apakah ada interaksi antara teknik mengajar dan aktualisasi diri siswa. Metode penelitian ini adalah penelitian kuantitatif dengan menggunakan desain eksperimen. Temuan penelitian adalah: (1) Teknik Drama berbeda secara signifikan dari teknik Guided Conversation Activity (GCA) untuk mengajar berbicara karena Fo lebih tinggi dari Ft. (2) keterampilan berbicara siswa yang memiliki aktualisasi diri tinggi berbeda secara signifikan dari mereka yang memiliki aktualisasi diri rendah jika dilihat dari hasil ANOVA karena Fo lebih tinggi dari Ft. (3) ada interaksi antara teknik mengajar dan aktualisasi diri untuk mengajar berbicara karena Fo lebih tinggi dari Ft.
\end{abstract}

Kata kunci: drama, guided conversation, percakapan terpimpin, berbicara.

\section{INTRODUCTION}

Indonesian government supports the spirit of having the ability of speaking English by facilitating education with curriculum that includes English speaking skill in every educational level. English is taught in elementary school starting from the 4th grade and had classified as a compulsory subject for junior and high schools, 
even it becomes one of the basic subjects to be passed within Ujian Akhir Nasional (National Examination). Accordingly, it can be assumed that Indonesian students have been studying English including speaking for about 10 years. However, even though the students officially study English in formal schools for quite a long time. Many of them still have some problems in speaking. They indeed receive many speaking materials from their teacher, but after they graduate, many of them cannot speak well. Further, students seem to have no motivation to speak in class because of their psychological barrier such as being afraid of making mistakes, being laughed by their friends, and being afraid of sharing their own. For many years, teaching speaking have been undervalued. English teachers have continued to teach speaking using traditional approach such as repetition of drills, memorization and practicing the conversation in front of the class. However, today world requires some strategies to reach the goal of teaching speaking skill. Drama and guided conversation are the examples. These techniques are able to be applied in teaching the first semester students of IKIP-PGRI Pontianak related to the phenomenon of the Asian students that has been stated above.

Drama, in this context, does not mean a classical play or a theatre performance. However, it is drama in education. Drama in Education (D.I.E) is the use of drama as a means of teaching across the curriculum. According to Landy (1982: 5), drama is elements - imitation, imagination, role-playing, and interpretation account for much of one's learning of language, movement and social behavior. Drama in education, also known as creative drama, is an improvisational, non-exhibitional, processed-centered form of drama in which participants are guided by a leader to imagine, enact, and reflect upon human experience. According to Landy (1982: 5), it requires both logical and intuitive thinking, personalizes knowledge and yields aesthetic pleasure. According to Katz (2000: 47) a learner involved in a drama activity will be called upon to practice several thinking skills such as inventing, generating, speculating, assimilating, clarifying, inducing, deducing, analyzing, accommodating, selecting, refining, sequencing and judging. 
It is thus apparent from the list of skills identified that drama in education has a significant contribution to make the development of higher order thinking skills. Another definition of drama as Rustelli (2006: 82) states, drama is written dialogue which involves a wide range of responses and gives stimuli for the development of speaking, listening, and writing activities. According to Schneider and Jackson (2000) process of drama is also suggested as a tool to promote literacy development through opportunities for dramatic play in early childhood settings within which children speak for a range of purposes in role. On physical theater, it has been similar connections between language, movement, and abstract thought (Sam: 2003). In addition; he states that somatic learning and the inseparability between the mind and body are important in cognitive development. From the theories, it can be concluded that there is a connection between mind and body with some tools that can help to develop the process of drama.

On the other hand, guided conversation is the activity that is often used by many teachers to teach speaking. The teacher dominates to control practice stage of speaking class activities so that students have the opportunity to accurately try out what they have learned. Guided conversation activity helps students' automatic responses using a specific formulaic expression or structure through practice of small and manageable chunks of language. These help to build confidence and automatic use of structures and expressions that have been arranged. These activities involve the teacher simply talking with the students, without any plan for teaching students about how to converse in English. Guided conversation activity technique is different from drama technique. According to Allen and Valette (1977: 89), it is a two-way dialogue style of teaching for introducing new grammatical structures. Activity for teaching and practicing speaking can be arranged along acontinuum from totally scripted speech, to guided output by the learners, to completely novel, self-directed output. More guided and controlled activities are needed because their oral production generally consists of isolated words and learned phrases within very predictable areas of need. In conclusion, GCA technique is a two-way dialog style of teaching for introducing new grammatical structures. The students are given a framework to build their sentences, but the 
actual choice of what they will say is left up to them; at least in part. Teachers can make guided conversation using a one-sided script and elicit the students speaking by letting them respond appropriately in the context (Allen andValette, 1977: 90). According to Molinsky (2002: 2), the guided conversation activity technique model is a proven process that instructors can use to teach dialogues, songs, and chants with procedures: (1) opening; (2) main activity (modeling conversation, present the model, set the scene, group choral repetition, the conversation based students' interest, follow up activities); (3) closing.

However, it should be known by the teachers that their students have different personality or individual differences that affect the students' different learning achievement. Self-actualization, another variable of individual differences is defined as the tendency to actualize, as little as possible, individual capacities in the world. Maslow (2006: 9) defines self-actualization as the desire for self-fulfillment, namely the tendency for him (the individual) to become actualized in what he is potential. This tendency might be phrased as the desire to become more and more what one is, to become everything that one is capable of becoming. Another definition of self-actualization is based on some theories that describe in the next sentence. Self-actualization (Suurküla) is usually understood as the realization of one's talents and powers. Goldberg had his own definition of self-actualization, "the tendency to actualize [the organism's] individual capacities as fully as possible is the basic drive, the only drive by which the life of an organism is determined." (Goldberg, 1982 , p.207).

Learning how to speak is an example of a self-actualizing process, where functions originally designed for other purposes are reorganized into the new function of speaking. This is very important, because it means that $99 \%$ of people have the in born ability to self-actualize to some degree, and therefore benefit from integration. Self-actualizing people are capable of being highly creative. Creativeness can be expressed in many dimensions by writing, speaking, playing, fantasies, or whatever, but self-actualizing do have moods of being creative. Maslow (2008:28) has said that a first-rate cook is better than a second-rate painter. 
Hence, creativeness can be expresses in many dimensions. Maslow (1962) also said, the growth of self-actualization refers to the need for personal growth and discovery that is present throughout a person's life. In teaching and learning process, the teacher's role is crucial in helping students to achieve self-actualization stage. The teacher should help the students in teaching and learning process so that the students can work and learn in their own way to reach new levels of competence. Furthermore, to be successful in learning speaking, students are required to be selfactualized. Therefore, there are some indicators of self-actualization that must be achieved by the students, they are: being spontaneous and natural, a high sense of humor (which tends to be thoughtful, philosophical, and constructive), accepting themselves, being creative, original, being problem-centered.

\section{METHOD}

The method which is used in this research is quantitative research using experimental design. An experimental research has three characteristics, covering: (1) control; (2) manipulation; and (3) treatment. The population was the first semester students of English Education Department of IKIP-PGRI Pontianak in the academic year 2016/2017. The researcher took the sample of the research by using cluster random sampling and devided the group into two. One became the experimental group and another one became the control group. The number of sample was 60 students for two groups of the research sample. Each group of the research sample consisted of 30 students. Furthermore, each of the sample group was divided based on their level of self-actualization: high self-actualization students and low self-actualization students.

In collecting the data, the researcher used two kind of instruments. They are oral test to test speaking skill and questionnaire to get information about selfactualization. Before the test given to the students, there was a try out to check the readibility of the test instruction of speaking test and and the validity of selfactualization test. In speaking test, the scoring criteria consists of five aspects, they

are fluency, grammar, vocabulary, pronunciation and comprehension. The researcher an inter-rater during the test in order to avoid subjectivity and personal bias. Furthermore, in this research, the questionnaire was used to obtain information 
about the students' self- actualization in some criterias: being spontaneous and natural; a high sense of humor which tends to be thoughtful, philosophical, and constructive (not destructive); accepting themselves, others, and human nature; being creative, original, and inventive, with a fresh, naïve, simple, and direct way of looking at life; being problem-centered, not self-centered or egoistical. The techniques used to anlyze the data in this research were descriptive and inferential analysis.

\section{RESEARCH FINDING AND DISCUSSIONS}

The data were analyzed and described into 8 points. The data in chapter four are obtained from the students' speaking score. The frequency of distribution includes mean, median, mode, and standard deviation. The summary of the computation is shown by the histogram and polygon. The data description is divided into 8 points. The result of the frequency distribution can be seen in table 1 .

Table 1. Frequency Distribution

\begin{tabular}{cccccccc}
\hline No. & Interaction & $\begin{array}{c}\text { Highest } \\
\text { Score }\end{array}$ & $\begin{array}{c}\text { Lowest } \\
\text { Score }\end{array}$ & Mean & Median & Mode & $\begin{array}{c}\text { Standard } \\
\text { Deviation }\end{array}$ \\
\hline $\mathbf{1}$ & $\mathrm{A}_{1}$ & 87 & 50 & 70.67 & 72.50 & 79.37 & 11.06 \\
$\mathbf{2}$ & $\mathrm{A}_{2}$ & 82 & 48 & 65.90 & 66.90 & 51.10 & 10.51 \\
$\mathbf{3}$ & $\mathrm{B}_{1}$ & 87 & 48 & 70.83 & 72.50 & 75.50 & 11.64 \\
$\mathbf{4}$ & $\mathrm{B}_{2}$ & 82 & 49 & 65.77 & 65.64 & 52 & 10.48 \\
$\mathbf{5}$ & $\mathrm{A}_{1} \mathrm{~B}_{1}$ & 87 & 68 & 78.83 & 77.83 & 76.83 & 5.38 \\
$\mathbf{6}$ & $\mathrm{A}_{1} \mathrm{~B}_{2}$ & 81 & 50 & 62.33 & 62.3 & 54.50 & 8.64 \\
$\mathbf{7}$ & $\mathrm{A}_{2} \mathrm{~B}_{1}$ & 80 & 50 & 62.66 & 64.12 & 51.38 & 9.78 \\
$\mathbf{8}$ & $\mathrm{A}_{2} \mathrm{~B}_{2}$ & 82 & 49 & 67.86 & 70.08 & 71.83 & 9.34 \\
\hline
\end{tabular}

Then, based on the resultof normality test the sample are in normal distribution. Because $L_{o}<L_{t}$ at the level of significance $(\alpha)=0.05$ and the summary of normality test can be seen in this following table. 
Table 2. The summary of Normality Test

\begin{tabular}{|c|c|c|c|c|c|c|}
\hline No & $\begin{array}{c}\text { Variable } \\
\text { s }\end{array}$ & $\begin{array}{c}\text { Number } \\
\text { of the } \\
\text { Data } \\
\end{array}$ & $\begin{array}{c}\alpha \\
(\mathbf{0 , 0 5})\end{array}$ & $\begin{array}{c}\text { Lo } \\
(\text { Lobtained } \\
\text { ) } \\
\end{array}$ & $\begin{array}{c}\mathbf{L}_{\mathbf{t}} \\
\left(\mathbf{L}_{\text {table }}\right)\end{array}$ & Description \\
\hline 1 & $\left(A_{1}\right)$ & 30 & 0.05 & 0.114 & 0.1610 & $\begin{array}{l}\mathrm{L}_{\mathrm{o}}<\mathrm{L}_{\mathrm{t}} \\
\text { Normal }\end{array}$ \\
\hline 2 & $\left(A_{2}\right)$. & 30 & 0.05 & 0.1080 & 0.1610 & $\begin{array}{l}\mathrm{L}_{\mathrm{o}}<\mathrm{L}_{\mathrm{t}} \\
\text { Normal }\end{array}$ \\
\hline 3 & $\left(B_{1}\right)$. & 30 & 0.05 & 0.1100 & 0.1610 & $\begin{array}{l}\mathrm{L}_{\mathrm{o}}<\mathrm{L}_{\mathrm{t}} \\
\text { Normal }\end{array}$ \\
\hline 4 & $\left(B_{2}\right)$. & 30 & 0.05 & 0.124 & 0.1610 & $\begin{array}{l}\mathrm{L}_{\mathrm{o}}<\mathrm{L}_{\mathrm{t}} \\
\text { Normal }\end{array}$ \\
\hline 5 & $\left(A_{1} B_{1}\right)$. & 15 & 0.05 & 0.1790 & 0.220 & $\begin{array}{l}\mathrm{L}_{\mathrm{o}}<\mathrm{L}_{\mathrm{t}} \\
\text { Normal }\end{array}$ \\
\hline 6 & $\left(A_{1} B_{2}\right)$. & 15 & 0.05 & 0.1720 & 0.220 & $\begin{array}{l}\mathrm{L}_{\mathrm{o}}<\mathrm{L}_{\mathrm{t}} \\
\text { Normal }\end{array}$ \\
\hline 7 & $\left(\mathrm{~A}_{2} \mathrm{~B}_{1}\right)$. & 15 & 0.05 & 0.1210 & 0.220 & $\begin{array}{l}\mathrm{L}_{\mathrm{o}}<\mathrm{L}_{\mathrm{t}} \\
\text { Normal }\end{array}$ \\
\hline 8 & $\left(A_{2} B_{2}\right)$. & 15 & 0.05 & 0.113 & 0.220 & $\begin{array}{l}\mathrm{L}_{\mathrm{o}}<\mathrm{L}_{\mathrm{t}} \\
\text { Normal }\end{array}$ \\
\hline
\end{tabular}

Homogeneity test is used to know whether the data are homogenious or not.

Table 3. Summary of Homogeneity Test

\begin{tabular}{|c|c|c|c|c|c|}
\hline Sample & Df & 1/df & $\mathbf{S}_{\mathrm{i}}^{2}$ & $\log S_{i}^{2}$ & (df) $\log \mathrm{S}_{\mathrm{i}}{ }^{2}$ \\
\hline 1 & 14 & 0,071429 & 27,55238 & 1,440159 & 20,16223 \\
\hline 2 & 14 & 0,071429 & 85,6 & 1,932474 & 27,05463 \\
\hline 3 & 14 & 0,071429 & 107,9524 & 2,033232 & 28,46525 \\
\hline 4 & 14 & 0,071429 & 110,381 & 2,042894 & 28,60052 \\
\hline$\sum$ & 56 & & & SUM & 104.2826 \\
\hline
\end{tabular}

Based on the result of computation above, it is found that $\chi_{0}^{2}(7.249)$ is lower than $\chi_{t}^{2} 95(3)(7.81)$.

After conducting the normality and homogeneity testing, the researcher conducted the computation of hypothesis testing. The multifactor analysis of variance (ANOVA) $2 \times 2$ is used to know whether $\mathrm{H}_{\mathrm{o}}$ is rejected or accepted. 
Table 4. The Summary of the Mean Score

\begin{tabular}{cccc}
\hline Self- & \multicolumn{2}{c}{ Teaching Methods } & Total \\
\cline { 2 - 3 } actualization & $\begin{array}{c}\text { Drama technique } \\
\left(\mathrm{A}_{1}\right)\end{array}$ & $\begin{array}{c}\text { Guided } \\
\text { conversation } \\
\text { technique } \\
\end{array}$ & \\
High $\left(\mathbf{B}_{1}\right)$ & 79.13 & 62.333 & 70.73 \\
Low $\left(\mathbf{B}_{2}\right)$ & 62.20 & 69.333 & 65.77 \\
Total & 70.6667 & 65.833 & \\
\hline
\end{tabular}

Table 5. The Summary of Multifactor Analysis of Variance

\begin{tabular}{lccccc}
\hline \multicolumn{1}{c}{ Source of Variance } & SS & Df & MS & $\mathbf{F}_{\mathbf{0}}$ & $\mathbf{F}_{\mathbf{t}(\mathbf{0 . 0 5})}$ \\
\hline $\begin{array}{l}\text { Between Columns } \\
\text { (Teaching methods A1 and A })\end{array}$ & 350.42 & 1 & 350.42 & 4.288 & 4.00 \\
$\begin{array}{l}\text { Between rows (Students' self-actualization } \\
\text { B }_{1} \text { and B }\end{array}$ & 370.02 & 1 & 370.02 & 4.465 & 4.00 \\
$\begin{array}{l}\text { Columns by Rows } \\
\text { (Interaction between A and B) }\end{array}$ & 2148.02 & 1 & 2148.02 & 25.92 & 4.00 \\
Between Groups & 2868.45 & 3 & 965.15 & & \\
Within Groups & 4640.80 & 56 & $\mathbf{8 2 . 8 7}$ & & \\
Total Variance (SS) & 7509.25 & 59 & 127.28 & & \\
\hline
\end{tabular}

From the table above, the conclussion are: (1) Because the result of $F_{o}$ (between columns) is (4.288) and the $F_{t}$ at the level of significance $(\alpha)=0.05$ is (4.00) in which $F_{o}(4.288)$ is higher than $F_{t}(4.00), H_{0}$ is rejected and drama technique differs significantly from guided conversation; (2) because the result of $F_{o}$ (between rows) is (4.465) and the $F_{t}$ at the level of significance $(\alpha)=0.05$ is (4.00) in which $F_{o}$ (4.465) is higher than $\mathrm{F}_{\mathrm{t}}$ (4.00), $\mathrm{H}_{0}$ is rejected and the difference between rows is significant; (3) because the result of $F_{o}$ interaction (columns by rows) is (25.92) and the $F_{t}$ at the level of significance $(\alpha)=0,05$ is (4.00) in which $F_{o}(25.92)$ is higher than $F_{t}(4.00), H_{0}$ is rejected and there is an interaction between two variables (teaching methods and students' self-actualization in teaching speaking). It means that, the result of students' speaking skill depends on their level of self-actualization.

Tukey test is used to find out the significant difference of means of every treatment with the other means. Tukey test compares the mean score of $\mathrm{A}_{1}$ and $\mathrm{A}_{2}, \mathrm{~B}_{1}$ and $\mathrm{B}_{2}$, 
$A_{1} B_{1}$ and $A_{1} B_{2}$, and $A_{2} B_{1}$ and $A_{2} B_{2}$. The summary can be seen from this following table.

Table 5. The Summary of Tukey Test

\begin{tabular}{llllll}
\hline Groups & $\mathbf{N}$ & $\mathbf{q}_{\mathbf{o}}$ & $\mathbf{q}_{\mathbf{t}}$ & Comparison & Status \\
\hline $\mathrm{A}_{1}$ and $\mathrm{A}_{2}$ & 60 & 4.1127 & 2.83 & $\mathrm{q}_{\mathrm{o}}>\mathrm{q}_{\mathrm{t}}$ & Significant \\
\hline $\mathrm{B}_{1}$ and $\mathrm{B}_{2}$ & 60 & 3.3157 & 2.83 & $\mathrm{q}_{\mathrm{o}}>\mathrm{q}_{\mathrm{t}}$ & Significant \\
\hline $\mathrm{A}_{1} \mathrm{~B}_{1}$ and & 30 & 9.7810 & 2.89 & $\mathrm{q}_{\mathrm{o}}>\mathrm{q}_{\mathrm{t}}$ & Significant \\
$\mathrm{A}_{2} \mathrm{~B}_{1}$ & & & & & \\
\hline $\mathrm{A}_{1} \mathrm{~B}_{2}$ and & 30 & 4.2883 & 2.89 & $\mathrm{q}_{\mathrm{o}}>\mathrm{q}_{\mathrm{t}}$ & Significant \\
$\mathrm{A}_{2} \mathrm{~B}_{2}$ & & & & &
\end{tabular}

\section{DISCUSSION}

Based on the research findings, it can be explained that:

(1) Drama is more effective than Guided Conversation Activity in teaching speaking. The effectiveness of the drama can be seen from the students' mean score (70.66) which is higher than the students' mean score of the control method or guided conversation (65.83). The finding of this research reveals that there is significant difference between teaching speaking using drama and the guided conversation to teach speaking

(2) Students with high self-actualization have better speaking skill than the students who have low self-actualization. The difference can be seen from the students' mean score of the high self-actualization students (70.73) which is higher than low self-actualization students (65.77) in their speaking skill. The finding of this research reveals that students having high self-actualization have better speaking skill than students having low self-actualization.

(3) There is an interaction between teaching methods and students' selfactualization to teach speaking skill. The interaction can be observed from the value of $F_{o}$ which is greater than $F_{t}$ at the level of significance $(\alpha)=0.05$. It can be concluded that there is an interdependence of students' speaking skill toward teaching techniques and students' self-actualization.

\section{CONCLUSSION}


Based on the result of the data analysis, the research findings are as follows: (1) Drama is more effective than guided conversation to teach speaking skill for the first semester students of IKIP-PGRI Pontianak in the academic year of 2016/2017; (2) The students having high self-actualization have better speaking skill than those having low self-actualization in the first semester students of IKIP-PGRI Pontianak in the academic year of 2016/2017; and (3) There is an interaction effect between teaching techniques and self-actualization on the students' speaking skill in first semester students of IKIP-PGRI Pontianak in the academic year of 2016/2017.

Based on the research findings, it can be concluded that Drama technique is an effective technique to teach speaking skill. It provides many advantages for the students. Furthermore, self-actualization also has important role for the learners. It can be seen that the students who have high self-actualization had better speaking skill than those having low. Students who have high self-actualization tend to be creative. Creative students are remarkable for their skill in combining some information and instruction with their experiences to reach their goals. On the contrary, the students having low self-actualization tend to be passive and less responsive in joining class activities.

\section{BIBLIOGRAPHY}

Aldavero, Vanesa, Alonso. 2008. Drama in the Development of Oral Spontaneous Communication. Encuentro 17. Retrieved on August 1, 2010 from www. encuentrojournal. Org/textos/

Allen, D. Edward. \& Valette, M. Rebecca. 1977. Classroom Techniques: Foreign Languages and English As a Second Language. USA: Waveland Pr. Inc

Al Nashash, A. H. 2006. Designing a Task- based Program and Measuring Its Effect on Oral and Written Communicative Skills among Jordanian EFL Secondary Stage Students. Unpublished Doctoral Dissertation, Amman Arab University.

Bailey, K. M., \& Savage, L. (Eds.). 1994. New Ways in Teaching Speaking. Alexandria,VA: Teachers of English to Speakers of Other Languages, Inc.

Bailey. M. Kathleen. 2005. Practical English: Language Teaching Speaking. USA: McGraw-Hill ESL/ELT. America. 
Creswell, John, W. 2008. Educational Research: Planning Conducting, and Evaluating Quantitative, and Qualitative Research. New Jersey: Pearson Education, Inc.

Desialova, Liubov. 2009 Using different forms of Drama in EFL. Classroom. Humanizing Language Teaching Magazine, issue 4. Retrieved on July 17, 2010 from http://www. hltmag.co.uk/aug09/sart07.htm.

Dougill, John. 1987. Drama Activities for Language Learner. London: Macmillan Publishers Ltd.

Du Bay, W. H. 2004. The Priciples of Readibility. California: Impact Information.

Fleming, Mike. 2006. Drama and Language Teaching: The Relevance of Wittgenstein's Concept of Language Games. Humanizing Language Teaching Magazine, issue 4 Retrieved on June 20, 2010 from http://www. hltmag.co.uk/jul06/mart01.htm.

Fraenkel, J.R. \& Wallen, N.E. 1990. How to Design and Evaluate Research in Education. New York: Mc.Graw Hill Pub Co.

Goldberg LR. 1982. From ace to zombie: Some explorations in the language of personality. In C. D. Spielberger \& J. N. Butcher (Eds.), Advances in personality assessment. Hillsdale, NJ: Erlbaum; 203-234.

Hall, Michael, L. 2008. Self-Actualization Psychology, USA: Neuro-Semantics Publications

Harmer. J, 2007. The Practice of English Language Teaching. USA: Pearson Longman ELT; 4th edition.

Heikkinen, H. 2004. Serious Playfulness. Drama Education Teachers. Vantaa: KVS Foundation.

Heikkinen, H. 2005. Drama Education Teaching, the Art of Examination! Jyväskylä: Minerva.

Holden, Susan. 1982. Drama in Language Teaching. London.

Holmberg, B. 1983. Guided Didactic Conversation in Distance Education. New York, NY: Routhledge.

Katz, S. 2000. Drama and Therapy in Education: The Double Mirror. Unpublished PHD thesis. University of Toronto.

Kayi, Hayriye. 2006. Teaching Speaking: Activities to Promote Speaking in a Second Language. University of Nevada. The Internet TESL Journal, Vol. XII, No. 11, November 2006. Retrieved on May 20, 2009 from http://iteslj.org 
Kothari C.R. 2007. Research Methodology Method and Techniques, New age international (p) Ltd., New Delhi.

Landy, R. S. 1982. Handbook of Educational Drama and Theater. London: Greenwood Press.

Lazaraton, A. 2001. Teaching Oral Skills. In M. Celce-Murcia (Ed.) Teaching English as A Second or Foreign Language (3rd ed., pp. 103-115). Boston: Heinle \& Heinle.

Luoma, Sari. 2004. Assessing Speaking. Cambridge: Cambridge University Press Manisha 2010. Difference Between Equity and Equality. Retrieved on December $\quad 8, \quad 2010$ from http://www.differencebetween.net/language/difference-betweenequity-and-equality/

Makita, Y. 1995. The Effectiveness of Dramatic/Role-playing Activities in the Japanese Language Classroom. Retrieved on August 8, 2010 from http://journals2.iranscience.net:800/meel.pacificu.edu/meel.pacificu.edu/pap ers/scholars/makita/makita.htm

Maslow, Abraham. 1966. Self-Actualization. Audio Cassette

Molinsky, S. J., Molinsky, B. Bliss. 2002. Side by Side: Student Book 4 (text only) 3rd (Third) Edition. USA: Pearson ESL.

Nation, I., \& Newton, J. 2009. Teaching ESL/EFL Listening and Speaking. New York: Routledge Press.

Nicholson, Helen. 2000. Teaching Drama 11-18. United Kingdom: Bloomsbury Publishing

Rastelli, L.R. 2006. Drama in Language Learning. Encuantro, 16, 82-94.

Richards, J. C., \& Rodgers, T. 1986. Approaches and Methods in Language Teaching: A Descriptive Analysis. Cambridge: Cambridge University Press.

Richard, Jack C. and Willy A. 2004. Renandya, Methodology in Language Teaching, Cambridge University Press.

R. J. Landy. 1982. Handbook of Educational Drama and Theatre. Westport, CT: Greenwood Press.

W. Y. Sam. 2003. Drama in Teaching English as a Second Language: A Communicative Approach. Retrieved on August 7, 2010 from http://www.melta.org.my/ET/1990/main8.html.

Schneider, J. J. and S. A.W. Jackson 2000. Process Drama: A Special Space and Place for Writing. The Reading Teacher, 54(1), 38-51.

Thombury, Scott. 2005. How To Teach Speaking. British: Pearson Education.

Toye. N., Prendiville, F. 2007. Speaking and Listening through Drama, 7-11. London: Paul Chapman Publishing. 